\title{
Analysis of Specificity of ecological insulation material thermal Parameters
}

\author{
Baiba Gaujena ${ }^{1, *}$, Jelena Tihana ${ }^{2}$, Anatolijs Borodinecs ${ }^{2}$ and Vladislavs Agapovs ${ }^{2}$ \\ ${ }^{1}$ Institute of Building Production, Riga Technical University, Latvia \\ ${ }^{2}$ Institute of Heat, Gas and Water Technology, Riga Technical University, Latvia
}

\begin{abstract}
This paper is devoted to analysis of insulation materials quality and characteristics, method for the determination of thermal conductivity coefficient and the influence of various factors on the thermal conductivity coefficient. The paper summarizes the estimated process consumption of thermal energy. The research is defined experimental hemp fiber-sheaves insulation plates manufactured in Latvia further specified actual parameter and quality - water absorption; thickness changes; drying process; thermal conductivity coefficient; thermal conductivity coefficient depending from moisture. Research is made using experimental hemp fiber-sheaves insulation pattern manufactured in Latvia - plates in size $300 \times 300 \mathrm{~mm}$. In research totally are used three hemp fiber-sheaves pattern series with different substance and extrusion modes. Each series consist from four plate with different thickness. As result of research is determined hemp fiber-sheaves insulation pattern Water absorption, dynamics of Drying process, Thickness changes, Thermal conductivity coefficient and Thermal conductivity coefficient depending from moisture.
\end{abstract}

\section{Introduction}

It is not only important in Latvia to look for a way to produce ecological and durable insulation materials from local natural fibers, it is important for all world to make innovations in production of materials. One of these materials can be hemp in Latvia.

Hemp is one of the oldest varieties of crops that has been widely developed for centuries in the world. Until the 19th century, hemp was one of the main ingredients for the production of useful products and products such as yarns, ropes, clothing, food, oil for luminaires and medical preparations [2]. In the last twenty years, and in particular in the European Union, hemp has largely regained its status and popularity. So far, no scientific research has been carried out in Latvia on the possibilities for the cultivation of hemp, technologies and prospects for use in various sectors of the economy [3, 4]. Therefore, scientific research is needed to find out what are the prospects for growing and using hemp, the role that they play in the interaction of sustainable agriculture and the environment.

\footnotetext{
${ }^{*}$ Corresponding author: baiba.gaujena@rtu.lv
} 
The tendency of the contemporary world is to constantly search for opportunities to save. The constant rise in energy prices and the dependence of specific regions on energy imports force our country not only to increase energy production from renewable energy sources - wind, solar, water, biomass, etc., but also to reduce dependence by reducing energy consumption. One example of austerity is the insulation of buildings.

A person always strives to improve his living or working space so that it is even warmer and more cosy. Medieval walls covered with beasts in the 18th century. The walls of wooden buildings settled down from the premises, in the 19th century. New solutions were introduced in the building with air-cavities in masonry walls and the roofing sheet as a wooden wall-insulating material. With the technical revolution, there are ongoing experiments in construction with new, unbreakable materials, which were not always the most suitable and the best. This process continues today. At a time when the price of energy resources has increased and interest in energy efficiency in the operation of buildings, an important part in solving energy saving issues in the construction sector is the complex and rational use of local raw materials by producing efficient thermal insulation materials. Modern insulation, regardless of the use of buildings - residential, administrative or industrial, promotes not only its basic function, but also improves noise and vibro isolation, as well as extends the life of insulating structures. Before proceeding to the development of a renovation (insulation) project, it is necessary to carry out building survey measures - an energy audit that allows determining the energy flow in the system and finding the best energy-saving solutions [1]. A qualitative audit will show the benefits of each measure and what energy efficiency measures will pay the fastest.

\section{Material and methods}

The research was carried out on experimental samples of hemp fiber-sheaves in Latvia plates with dimensions of $300 \times 300 \mathrm{~mm}$ (see Figure 1).

In the research were studied following parameters:

1) Water absorption, $W$;

2) Drying process;

3) Thermal conductivity coefficient, $\lambda$.

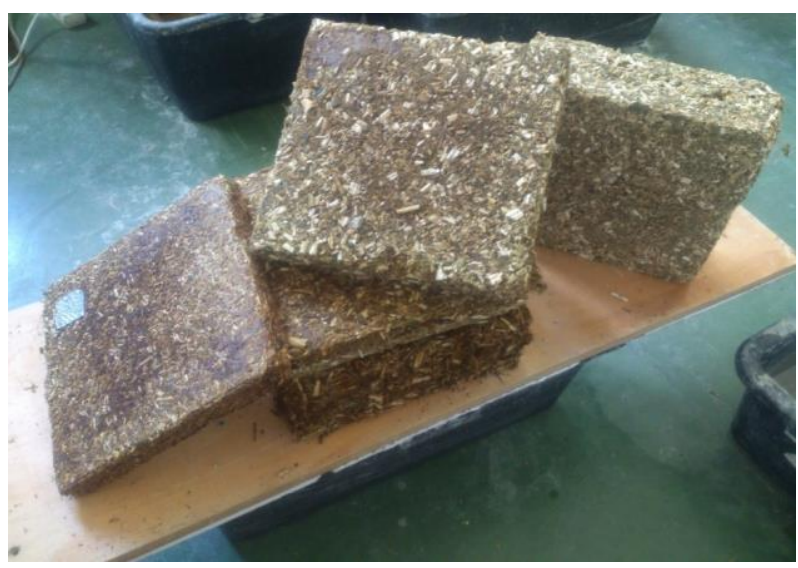

Fig. 1. Hemp fiber-sheaves with dimensions 300x300 mm. 
To make samples of panels, it was necessary to mix a preserved fiber-spray mixture with shredded straw of dry hemp. The first mixture has been milled with the help of two extruders and after it mixed together, and then with the special mill milled till final texture. A ready-made hemp fiber mixture is dried at a temperature of $+150^{\circ} \mathrm{C}$ [6]. In the process of manufacturing fibrous slabs, binders should be bonded in fibers so that the slabs are stable, with a durable shape and expected properties. Synthetic binders are the most commonly used in the manufacture of fiber boards [5].

For the manufacture the plates, material was blended with PF and/or UF glues: Phenol formaldehyde resin glue (PF) - Glues used for the manufacture of phenol formaldehyde resins - solutions are widely used in various industries. For synthesis of these glues, the main raw materials are formaldehyde and phenol and Carbamide-formaldehyde resin glue (UF) - Glue is the largest class of amino acids and the most used indoor binder used in plywood, particle board and fiber board technology. UF resin glue has several advantages: low price, non-combustible, light colour and fast vulcanization.

Samples of hemp fiber-sheaves are pressed on a pressed press on a press-heated press. The principal pressure scheme of hemp fiber-sheaves is shown in Figure 2. The pressing takes place in several stages. Each stage has a specified compression time under pressure and a distance between the heating surfaces. After all steps, the lower platform of the press is lowered to zero and the plate sample is automatically removed from the press.

\section{Conductivity plate Heat}

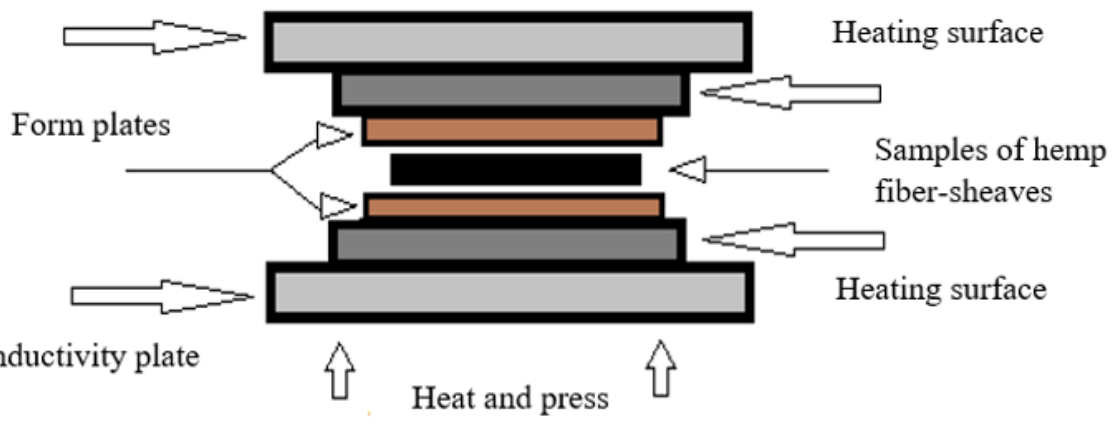

Fig. 2. Pressure scheme of hemp fiber-sheaves.

\subsection{Water absorption}

The water absorption is the ability of the material to absorb water and retain it in pores. The water absorption is the ratio of the dry mass of the sample to the water content of the impregnated sample. It is understandable that as a water absorption adversely affects the properties of an insulation material, increasing thermal conductivity and density.

The water absorption is determined on 3 different hemp fiber-sheaves samples selected from each series. Samples are measured and weighed.

The samples are placed on the pallet in a water bath and fixed with the weight. Then filled the water with the temperature of $20 \pm 5^{\circ} \mathrm{C}$. Water are filled that the water level of it is at least $10 \mathrm{~mm}$ higher than the upper edge of the samples. After 1 hour, the samples are removed, allowing throw away the residual water from the weigh. After 24 hours the 
procedure is repeated.

After impregnating the samples with water, they are placed in a drying oven and dried at a temperature of $60^{\circ} \mathrm{C}$. The results are recorded at 1,2, 24 and 48 hours, continuing the drying process until the last two results do not differ by more than $0.2 \%$. The percentage by mass of water absorption for each sample of hemp fiber-sheaves can be determined by the formula:

$$
W_{m}=\frac{m_{s}-m_{p}}{m_{s}} * 100, \%
$$

where $\quad m_{s}-$ mass of dry sample, $\mathrm{kg}$;

$$
\mathrm{m}_{\mathrm{p}}-\text { mass of water impregnated sample, } \mathrm{kg} \text {. }
$$

Additionally, changes in thickness for dry and water impregnated samples can also be determined from the formula:

$$
W_{b}=\frac{m_{1}-m_{2}}{m_{2}} * 100 \%
$$

$$
\begin{aligned}
& \text { where } \quad \mathrm{W}_{\mathrm{b}}-\text { coefficient of variation of thickness, \%; } \\
& \mathrm{m}_{1}-\text { thickness before submerge in water, } \mathrm{mm} ; \\
& \mathrm{m}_{2}-\text { thickness after submerge in water, } \mathrm{mm} .
\end{aligned}
$$

\subsection{Drying process}

As it is very difficult to avoid insulation moisture effects during transportation, installation and operation, it is important to study the drying process that is close to the natural conditions of the insulation material.

Determination of the drying process was performed on 3 different hemp fiber-sheaves samples selected from each series. Samples are measured and weighed.

The samples are placed on the pallet in a water bath and fixed with the weight. Then filled the water with the temperature of $20 \pm 5^{\circ} \mathrm{C}$. Water are filled that the water level of it is at least $10 \mathrm{~mm}$ higher than the upper edge of the samples. After 1 hour, the samples are removed, allowing throw away the residual water from the weigh. After 24 hours the procedure is repeated.

During water absorption the samples were weighed after 2 hours, 1, 2, and 3 days. The samples were additionally dried in a drying oven at the temperature of $30^{\circ} \mathrm{C}$, after 1 and 4 hours' samples were weighted. Drying was continued in a drying oven at the temperature of $60^{\circ} \mathrm{C}$, and weighted the same as way - after 1 and 4 hours.

\subsection{Thermal conductivity coefficient}

Heat flow meter FOX600 by Lasercomp is used to determine the thermal conductivity of the samples.

Determination of the thermal conductivity coefficients is carried out on each hemp fiber-sheaves sample. Before measuring the thermal conductivity, are measured the thickness of the samples. Measurements are recorded. The surface of the samples is cleaned of dirt and should be smooth, in accordance with the standard it is necessary to ensure 
maximum contact with the working surfaces of the board of heat flow mete FOX600.

In order to avoid the declared values conversion measurements were made according to certain conditions. Determination of the thermal conductivity of the samples was carried out on all samples - dry (after drying) and after conditioning at $23^{\circ} \mathrm{C}$ and at $50 \%$ relative humidity and in natural laboratory conditions.

The following parameters were installed on the Lasercomp heat flow meter FOX600:

1) temperature of hot plate $-20^{\circ} \mathrm{C}$;

2) temperature of cold plate $-0^{\circ} \mathrm{C}$.

In order to determine the declared thermal conductivity coefficient for samples of hemp fiber-sheaves, according to standard B LVS EN 10456: 2008, the calculation is required. The average thermal conductivity coefficient is obtained as the average arithmetic number of all measured data:

$$
\bar{\lambda}=\frac{\sum_{n} \lambda}{n}, \frac{W}{m * K}
$$

where $\quad \bar{\lambda}$ - average value;

$\mathrm{n}$ - amount of measurements.

To determine the thermal conductivity coefficient at different humidity, one sample of each series was artificially wetted under laboratory conditions and was immediately tested with the Lasercomp heat flow meter FOX600. The results are shown in graph how thermal conductivity coefficient changes depending on moisture (see Figure 3).

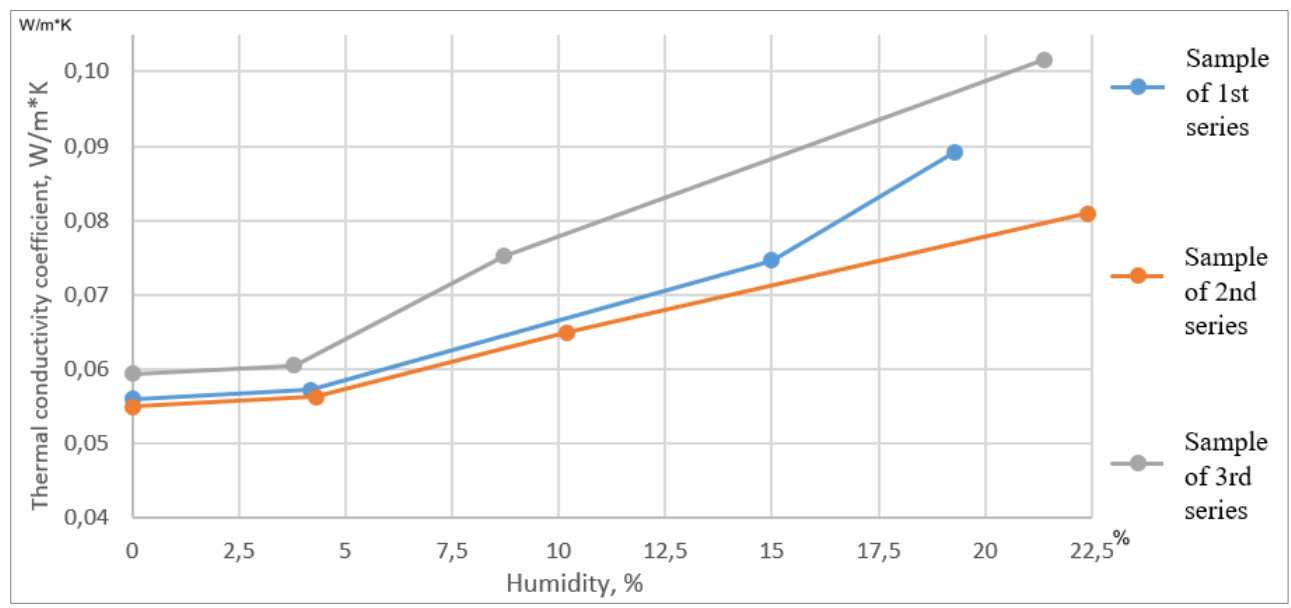

Fig. 3. Thermal conductivity coefficient depending from moisture.

\section{Results}

\subsection{Water absorption}

Samples of hemp fiber-sheaves show a high water absorption. The samples of 1 st series shown the average water absorption $-201.9 \%$ by mass and $36.2 \%$ by volume, 2 nd series $202.8 \%$ by mass and $40.2 \%$ by volume but 3 rd series $-189.2 \%$ and by $48.0 \%$ by volume. 
Of course, it should be taken into account that, under real conditions, the constructions consist of a layer of wind protection, a vapour barrier and a render (see Figure 4), therefore, in theory it is not possible for a layer of insulation to absorb such a large amount of water. Basically, the correct building structures, the insulation layer is enclosed and protected from the influence of the external environment. The moisture in the insulation layer can enter into a poor waterproofing solution or damage or condensation as a result of the difference of inside and outside temperature of the building (dew point).

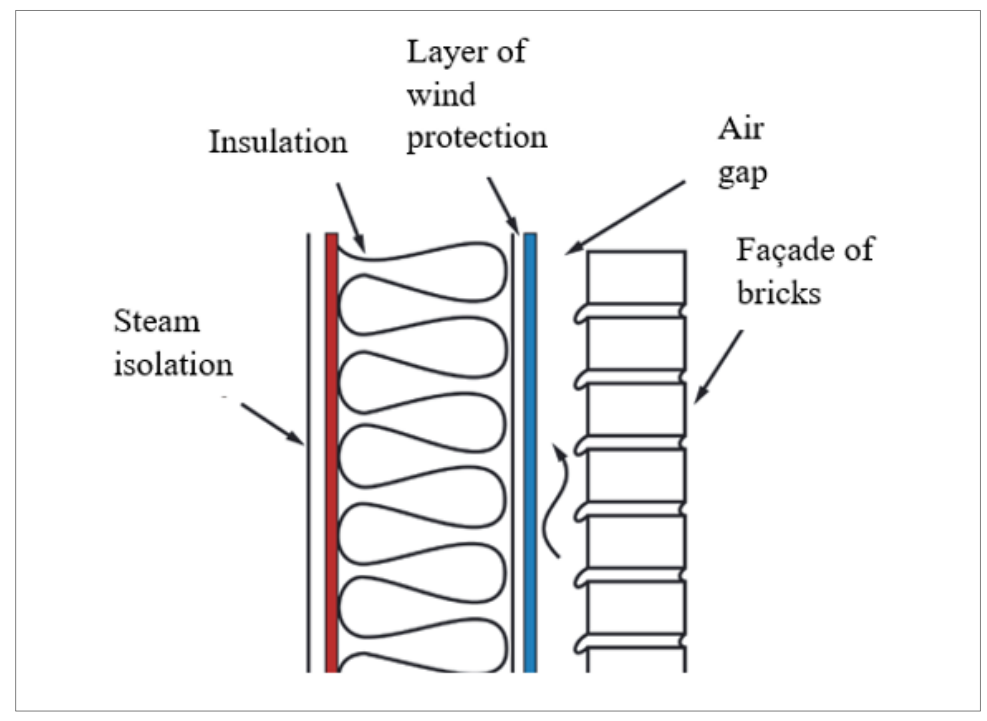

Fig. 4. Scheme of insulation layers.

It is difficult to compare the insulation materials available on the market. Insulation materials such as foamed polystyrene, extruded polystyrene foam, cufflinks, water absorption is below of the limit 5\%. In fact, insulation slabs of hemp fiber-sheaves, like glass and stone wool, should not come in contact with water. In any case, the samples of hemp fiber-sheaves show that the material have to be developed and applied with hydrophobic procedure.

Changes in thickness of the samples of hemp fiber-sheaves are within the range of $5 \%$, which are acceptable for organic materials with open pores.

As a result of the experiment, a water absorption of hemp fiber-sheaves was determined. The large water absorption badly affects to the properties of the insulation material - the thermal conductivity coefficient and the volume mass increase. After determining the water absorption, the dynamics of the drying process must be investigated. How long does the insulation material is drying up and whether the technical properties of the material have been returned?

\subsection{Drying process}

In the laboratory the drying process we can assimilate to the ideal weather conditions for insulation, but in real conditions of building constructions are less favourable (rain, temperature fluctuations, low average temperatures).

The experiment shows the water absorption influence to samples after keeping them in 
water 24 hours. The samples of 1 st series shown the average water absorption $252 \%$ by mass, the 2 nd series $-270 \%$ by mass and for the 3 rd series $-261 \%$. The drying process under laboratory conditions at the temperature of $20 \pm 2{ }^{\circ} \mathrm{C}$ was observed for three days. The samples of the first series dried up $97 \%$ compared to the water impregnated samples, the 2 nd series $-128 \%$ and the 3 rd series $-124 \%$.

The drying process was continued in a drying oven at the temperature of $30^{\circ} \mathrm{C}$ overnight. Samples of 1 st series dried up to $143 \%$ compared to the water impregnated samples, the 2 nd series - $187 \%$ and the 3 rd series - 196\%. At the end of the drying process, the samples were dried in the oven at $60^{\circ} \mathrm{C}$ overnight until complete drying. Samples of $1 \mathrm{st}$ series dried up to $210 \%$ compared to the water impregnated samples, 2 nd series $-279 \%$ and the 3 rd series $-286 \%$.

From the experimental data, a moisture content schedule was constructed depending on the drying process (see Figure 5).

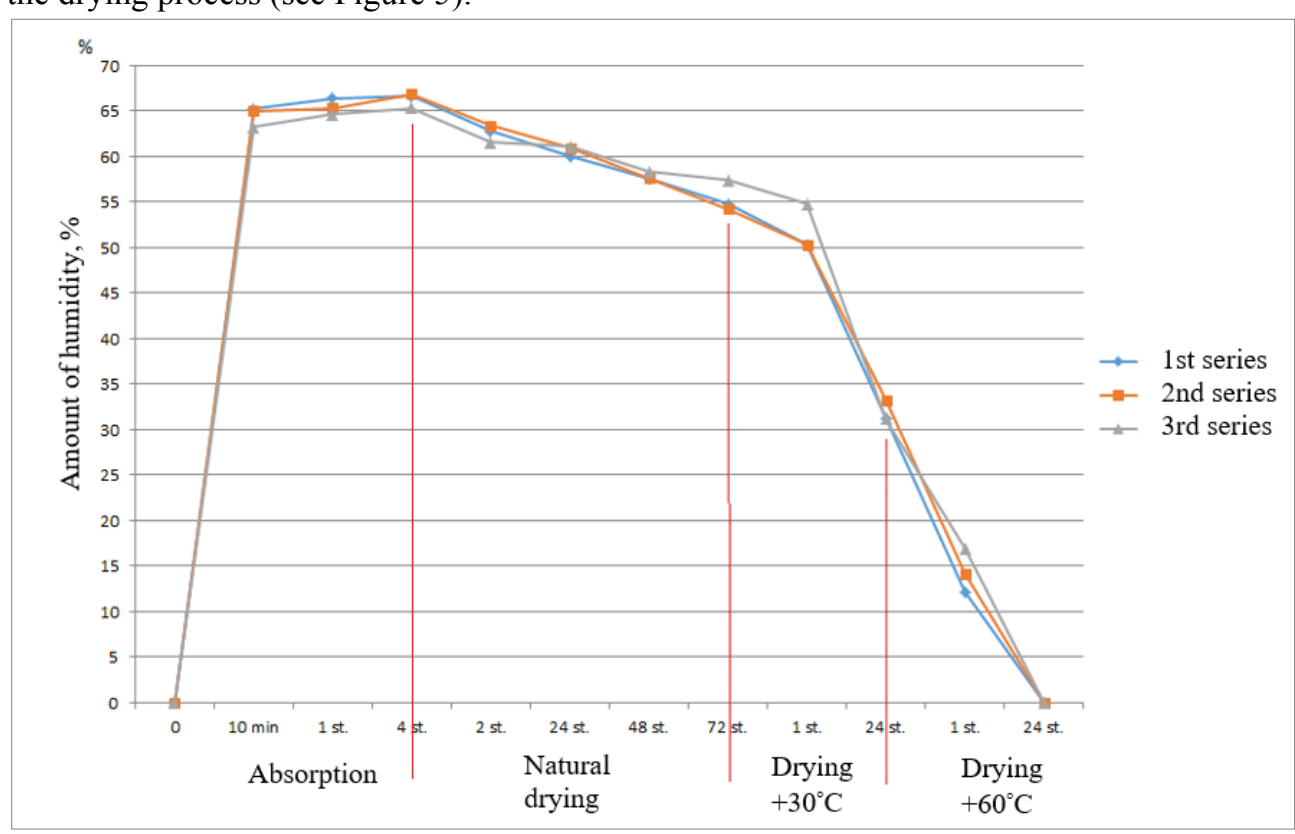

Fig. 5. The amount of moisture depending on the drying process.

It is understandable that under real conditions the insulation materials in constructions can't completely dry naturally. More attention should be paid to excess moisture that there haven't be situation that moisture can't drain out. Also it should be taken into account that the insulation material in the structure is in interaction with other materials and partially covered (at least from three sides). Of course, it more applies on constructions like roofs and other similar horizontal structures. The facade can be exposed from rain water when it's filtered through a decorative layer.

The results of the drying process only confirmed that the hemp fiber-sheaves should not come into the contact with water.

\subsection{Thermal conductivity coefficient}

Because of limited number of samples which were used for the research (4 samples per 
series), it was not possible to comply all the standard requirements during the experiment. But the research data shows the average thermal conductivity coefficient of the 1 st series samples is $0.0544 \frac{W}{m * K}$, the 2nd series $-0.0594 \frac{W}{m * K}$ and the 3rd series $-0.0655 \frac{W}{m * K}$.

The declared thermal conductivity coefficient of the samples of hemp fiber-sheaves, according to standard B annex to LVS EN 10456: 2008 [39], for the 1st series is $0.059 \frac{\mathrm{W}}{m * K}$, for the 2nd series - $0.068 \frac{W}{m * K}$ and for the 3rd series $-0.08 \frac{W}{m * K}$.

The large difference between the actual and the declared thermal conductivity coefficient is because of the disability to comply the requirements of the standard LVS EN 10456: 2008 [39] for the number of samples to be tested. According to the standard requirements, there must be measurements of 10 samples, but only 3 measurements were made in this research. Therefore, the declared thermal conductivity coefficient is only informative.

Under laboratory conditions artificially wetted the samples, it is impossible to ensure a uniform distribution of moisture, which generally leads to an error in measurements. In natural conditions this process is not so smooth as well. However, comparative measurements confirm how the water enters the material increases the thermal conductivity (see Figure 3). And at a certain amount of moisture $(\geq 20 \%)$, the insulation material stops perform its main function.

When the samples of hemp fiber-sheaves dry up, the values of the thermal conductivity returns close to the "start-up" results. But there is a possibility that the insulation material of hemp fiber-sheaves will be not able to dry completely without special help in natural conditions.

\section{Conclusion}

Before research of hemp fiber-sheaves as an insulation material the information was collected on various insulation materials which are available in Latvia - polystyrene foam (EPS), mineral wool, stone and glass wool, ecowool, foamed polystyrene-graphite granules, powders, fiber and hemp wool, fiber slabs, fibrolite slabs and magnesite sheets.

The thermal conductivity of insulation materials was summarized - thermal conductivity coefficient, volumetric mass, specific heat, heat resistance, heat transfer coefficient, water resistance coefficient, moisture conversion coefficient, material moisture content by mass or volume, material heat recovery and mechanical properties. On this basis, the main selection criteria for insulation materials were determined.

Separately was studied the sowing and harvesting of hemp in Latvia, as well as possibilities of use, including as insulation material. The benefits of insulation of hemp were analyzed, for example, the production of insulation of hemp already requires a significant (15 times less) energy consumption than the process of production of foamglass.

More value was paid for the process and method for determining the thermal conductivity coefficient and were set the factors that affect the thermal conductivity coefficient. They depend on geometrical dimensions, size stability, structure, volume, moisture, temperature differences, material structure, pore size, type and location of them, chemical composition and molecular structure, surface emission coefficient, from accidental operational and technological factors.

The main of these factors are: 
1) Thermal conductivity depending of the aging of the material;

2) Mistakes in the production process of insulation;

3) Fire safety;

4) Wind and humidity effects;

5) Geometric stability;

6) Cold bridges in wall constructions.

In general, the research shows that the development of technologies in the field of insulation materials, new insulation materials and technologies are being explored and created. However, there is a lot of different types of insulation materials to offer, and it is almost not possible to find a universal insulating material for each technical solution. Even can say that each insulation material has both positive and negative properties. The choice of insulation material depends on many factors and peculiarities of a particular technical solution. It is necessary to choose the right insulation material for specific working conditions, strictly follow to the production process of a certain material and pay more attention to the installation of the material on the construction site.

As the results of research show, there are development opportunities for samples of hemp fiber-sheaves producing process in Latvia. However, it is necessary to continue research and do more experiments to improve and stabilize the thermal and mechanical properties of the hemp fiber-sheaves:

1) Optimization of bonding process (glue);

2) Optimization of the proportion of fiber-spray mixtures with shredded shoots of dry stem of hemp;

3) The possibility of using hydrophobicity should be studied;

4) Improving the efficiency of the pressing mode.

\section{References}

1. Videvuds Ārijs Lapsa. Ēku siltumizolācijas problēmas un to risinājumi. Latvijas būvniecība 5 (16)/09, p. 50-54.

2. Baltiņa, I., Zamuška, Z., Stramkale, V., Strazds, G. Kan̦epju audzēšanas un šķiedru pārstrādes iespējas Latvijā. Latgales Tautsaimniecības pētījumi: sociālo zinātņu žurnāls (2012) No.1(4), p. 42-53. ISSN 1691-5828

3. Stikute, A., Kukle, S. Kaņepju spaļu izmantošanas iespēju izpēte. No: 52. RTU Studentu zinātniskās un tehniskās konferences materiāli, Latvija, Rīga, April 27, 2011. Rīga: RTU Izdevniecība (2011) p. 253 - 253. ISBN 9789934102608.

4. Performance characteristics and practical applications of common building thermal insulation materials. Al-Homoud, M.S. 2005, Building and Environment, Vol. 40, p. 353 - 366. Available from: doi: 10.1016/j.buildenv.2004.05.013. ISSN: 03601323.

5. LVS EN ISO 10456+AC:2013 L "Būvmateriāli un būvizstrādājumi. Higrotermiskās īpašības. Projektos lietojamo vērtību tabulas un deklarēto un aprēķina siltumtehnisko vērtību noteikšanas procedūras".

6. Kirilovs, E., Gusovius, H., Dolacis, J., Kukle, S. Innovative Fibreboard from WetPreserved Hemp. No: Research for Rural Development 2013, Latvija, Jelgava, May 15.-17. (2013) Jelgava: Latvia University of Agriculture (2013) p. 200 - 206. ISSN $1691-4031$. 